\title{
Where Are The Women? A Contemporary Feminist IR Critique Of Security In World Politics
}

\author{
Saima Siddiqui \\ Department of Political Science \\ Memorial University of Newfoundland, Canada
}

\begin{abstract}
The international relations (IR) discourse has been a subject of feminist critique for over two decades. One of the key concerns for this assessment is marginalisation women and gender perspectives in security studies. Many feminists have argued that world politics remain a masculine domain where fewer women are visible at the decision making positions. The association of masculinity and security has allowed feminist scholars to identify possible impediments for this inadequacy. This article explores the "gendered" nature of international relations from a contemporary feminist perspective by means of critiquing the realist theory in international relations. For this purpose, the article is going to examine hegemonic masculinity and how it links with theoretical ideology and practice of realism to socially construct the dominant masculine and weak feminine gender hierarchies in world politics.

$$
\begin{aligned}
& \text { تلخيصِ مقال }
\end{aligned}
$$

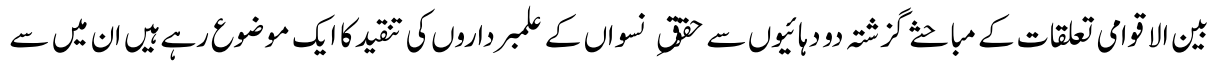

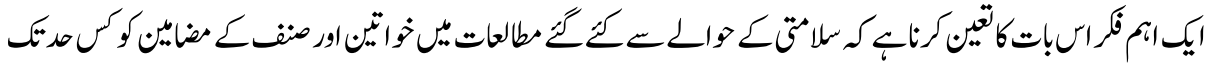

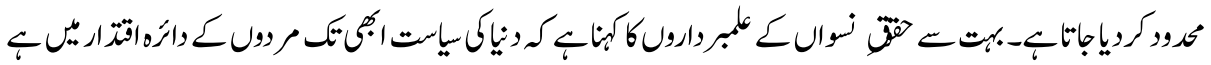

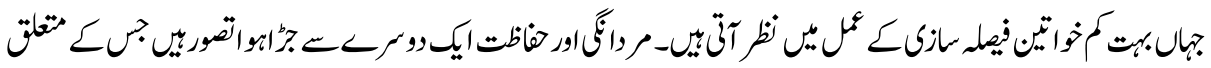

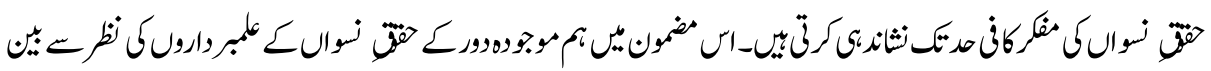

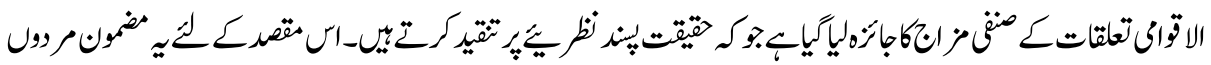

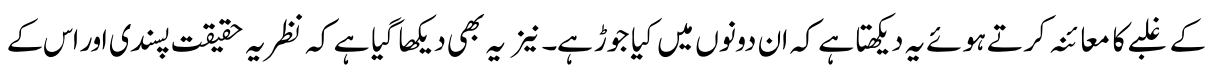

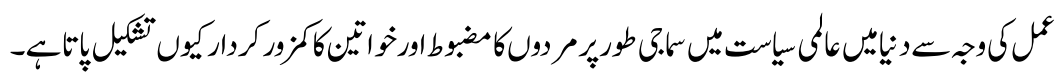

\section{Introduction}

For over two decades, the international relations (IR) discourse has been subject of feminist critique. One of the key concerns for this assessment is the marginalisation of women in security studies. Many feminists argue that security is still paradigmatically a male dominated area of world politics where men occupy higher positions, drafting laws and implanting policies while, relatively fewer women are visible at decision making 
positions (Tickner, 1992). The association of masculinity and security has allowed feminist scholars to identify possible impediments for this inadequacy. The stereotyping and perceptions of women's roles and abilities; presence of fewer women role models in politics; media imbalances in the treatment of women politicians, family commitments; masculine political environment, failure of political parties to bolster women candidates, lack of finances and exclusion from informal party networks prevent women to participate into higher political arena (Elder, 2004; Goodyear-Grant in Trimble and Arscott, 2004; Burns et al, 1997, Verba et al, 1997 and Schlozman et al, 1994).

Others scholars point out at the gendered nature of the realism, the dominant IR theory that view security only as "a partial view of reality" (Romaniuk, 2009:145) reinforcing the belief that core areas of security such as foreign policy and conflict are least appropriate for women (Tickner, 1988). Characteristics such as strength, power, autonomy, independence, and rationality are related to "manliness," throughout history and are valued upon which we entrust the conduct of our foreign policy and the defence of our national interest (Tickner, 1992: 6). Frequently, manliness has with violence and the use of force, a type of behaviour that, when conducted in the international arena has been valorised and applauded in the name of defending one's country. Women, in security issues are perceived as being too emotional and too weak for the tough life-anddeath decisions required for the nation's defence (Steans, 1998).

The extent to which the security is thoroughly masculinised that women's voices are considered inauthentic, this paper is examines why security is defined in terms of masculine values? My hypothesis is that realism has defined security in a narrow "statecentric, militaristic" perspective, which is also emanated from a masculine bias inherent because it has a deep correlation with certain stereotypical masculine values i.e. Hegemonic Masculinity. According to R. W. Connell (2005), hegemonic masculinity is understood as the "pattern of practice that allowed men's dominance over women to continue". It is this appreciation of certain masculine behaviour and opposition of devalued femininity is upon which realism relies heavily for its analysis. According to contemporary feminist thought, hegemonic masculinity is a social construction projected onto the international behaviour of states (Tickner, 2001). For these reasons, men have been seen as rightfully operating in the public domain while women have been relegated to the private, because they are seen as weak, peaceful, cooperative and reliant on others for protection (Hudson, 2005). The feminine characteristics, in these socially constructed gendered binaries, become the devalued "other", needing protection (Romaniuk, 2009:145). The review of security studies from feminist perspective in international relations is essential because presence of masculine in higher levels of politics limits the visibility of women in decision making process and devalues their experiences in public sphere (Cronje, 2010). Including women's perspective to security by re-examining the traditional concepts of international relations theory would open the possibilities for 
multi-actor approach in resolving foreign policy and security issues (Tickner, 1988 and Murphy, 1996). In order to validate my hypothesis, I am exploring the gendered nature of international relations from a contemporary feminist perspective by critiquing the theory of realism and its shortcomings in viewing security issues in world politics. In this critique, I am examining hegemonic masculinity and how it links the realist theory to socially construct the dominant masculine and weak feminine gender hierarchies. Finally, I conclude my paper by offering a summary of the arguments.

\section{The “Gendered" Nature of Security}

The term security is a highly contested concept, subject to a myriad of definitions (Blanchard, 2003). While there is no single precise definition, traditional conceptions envision the state as "guarantor of the security of its citizens from the threats of other states" (Romaniuk, 2009:144). Sovereign states are main actors in an international system engaged in maximising power to achieve their desired goals and the pursuit of power is through war thus security is tied to its military and its "preparedness" to fight (Tickner, 1992:37). A number of feminist scholars observe realist theory is constructed by men, seen through male eyes and apprehended through male sensibilities. The central concern of realism is drawn on the historical writings of the classical Greeks as well as on those of early modern Western political theorists such as Machiavelli, Hobbes, and Rousseau to understand the behaviour of nation states (Bechler, 2008:1). Since men have been ascribed certain characteristics as "[s]trength, power, autonomy, independence and rationality" in these writings, they have been viewed as rightfully operating in the public domain while women have been relegated to the private, because they are seen as weak, peaceful, cooperative and reliant on others for protection (Hudson, 2005: 155).

Charlotte Hooper (2001) in her text suggests the domination of masculine perspectives in states is the consequence of certain stereotypical masculine behaviour that asserts unequal hierarchy over women. She associated this particular masculine value to "hegemonic masculinity"1 linking to the gendered thought behind realism. By definition,

'Hegemonic masculinity' refers to a particular idealized image of masculinity in relation to which images of femininity and other masculinities are marginalized and subordinated. The hegemonic ideal of masculinity in current Western culture is a man who is independent, risk-taking, aggressive, heterosexual and rational (Barrett in Whitehead and Barrett, 2001:79).

This means, hegemonic masculinity is power over women and "prestige of men at the expense of the opposite sex [women] in terms of strength, self-reliance, breadwinning capacity and sexual performance" (Tosh in Dudkin and Tosh, 2004:51). It also means hegemonic masculinity is not only accountable for dominance of men over women but 
also in formulation of masculinity and femininity as two distinctive norms within and outside the public/private sphere in a society. A feminist IR analysis to this definition pertains to the "idealised model" of masculinity, behaviour utilised and presented by states to legitimise national interests and security (Tickner 2001:49).

J. Ann Tickner further notes, 'Nowhere in the public realm are these stereotypical gender [and sex] images more apparent than in the realm of international politics, where the characteristics associated with hegemonic masculinity are projected onto the behaviour of states whose success as international actors is measured in terms of their power capabilities and capacity for self-help and autonomy" (Tickner 1992:6-7).

The debate around hegemonic masculinity is largely focused on the unequal hierarchy of the two genders. The construction of internal boundaries between the 'public 'and 'private' realms of society, where men had the privileged to participate in the public life, while women largely remained inside private sphere, resulted in imbalanced of power structure that worked against women and evoked gendered constructed of self and other that privileged hegemonic construction of masculinity.

The central structuring principle of hegemonic masculinity is power over women and so it finds a closer association with the concept of patriarchy. The attributes which combines the two concepts together are "power and prestige of men at the expense of the opposite sex [women] in terms of strength, self-reliance, breadwinning capacity and sexual performance" (ibid, p.51). In short, hegemonic masculinity combines with patriarchy as it imposes authority over women without doubt and as most men openly enforce their power of sex while at a same time benefiting from prevailing structures of gender relations. ${ }^{2}$ Most importantly, on practical terms, the hegemonic masculinity and patriarchy are accountable in formulating the debate around masculine and feminine norms and the public/private sphere that divides both the genders.

According to Jill Stean the literature within the imbalance of power with genders is largely focus around the construction of the terms 'masculine' and 'feminine' (Steans, 2006: 11). In all cultures of the world there are certain emotional, psychological norms that define and distinguish men from. Gender refers not to what men and women are biologically (sexes) but to the ideological and material relations that exist between the two. In any given society, not only the social institutions and practices that produce and reproduce gender identities, gender roles and gender relations but also, a person's gender plays a crucial factor in deciding 'who gets what', 'who can do what' and 'what one is permitted to be in a given society' (ibid:8). Further, ideologies and discourse on gender play a key role in producing and reproducing certain forms of identities and power relationships. Historically, the concept of hegemonic masculinity is closely associated with their gender roles frequently suggesting male-identified roles important and 
deserving compared to female-identified roles. For example, men performing the role of 'breadwinners' is an indication of hunting and aggressive while female role of 'housewives' is an indication of gathering and passive. Although, not always easy to pinpoint but this constructed gender identity pose a distinction between public and private activities and the range of social and familial roles that both men and women. As Du Bois (1975), suggest from the illustration of lives of men and women in the wake of ninetieth century Europe that men emerged from their earlier familial roles to enjoy the participation in the public sphere while women largely remain inside the private sphere, even though an overwhelmingly unmarried women for whom the factory period was a brief episode before marriage. Adult women remained almost entirely within the private sphere, defined politically, economically and socially by their familial roles. Thus the public sphere became a man's domain, while private, women's (ibid).

The phenomenon of imbalance of power between men and women takes us back to the beginning of our argument where I mentioned that it is dominance of masculine power which is key impediment behind women participating and reaching higher in politics. This power is played through hegemonic masculinity producing men's power and authority over women both directly and indirectly. It can be understood from the above debate how dominant concepts hegemonic masculinity constructs the imbalance of power between men and women, which results in the underrepresentation of the later at the policy making levels politics. Further, these concepts are also responsible in construction of gender identity by suggesting a distinctive role for men and women forcing women in a situation where they face multiple burdens as they try and balance between public and private sphere.

Ann Philips offers a glimpse on the lives of women trying to experience their potentials in politics: Women are prevented from participating in public life because of the way their private lives are run. The division of labour between women and men constitutes for most women a double burden of work ". . . . The mere pressures of time will keep most women out of any of the processes of decision-making . . the way our private lives are organized promotes male involvement and reduces female participation" (in Burns et al, 1997: 373).

Philips statement complements to how imbalance of power highlights the stereotypical role of men, dominating masculine norms and compressing women compressing women's abilities and inspirations to participate fully in political life. Not only that, but also how these dominating masculine norms define and represent women identity in connection to national security debate.

The above example is an indicator as to how the identity of men as breadwinner and that of women as caregiver associates with their active vs. passive participation in world 
politics. Since women are time and resource constraint their experience as decision makers are likely to be invalid compared to men that are more active in politics. This couple with the gender identity norms where men as breadwinner are considered to be more emotionally strong and aggressive and therefore, natural protectors compared to women perceived as passive, caregivers and to be protected (Weldes, 1999; Tickner, 1988; Booth, 1968; Millett, 1968 and Freemen; 1971).

In short, these differences in perception, means that dominating perspectives becoming authentic voices of national security debate. In case of security debate, this means problems and issues are defined and selected at the policy levels with the masculine perspective, interests and knowledge being authentic security solutions, while that of women are given due priority and authenticity. As Baylis and Smith noted that at conventional policymaking this difference suggests -objectivity vs. Subjectivity, reasons vs. Emotion, culture vs. Nature, self vs. Other with Nature and Self has always been the masculine state while the subjectivity, emotion and other is the perspective of those outside the power i.e. women). In short, Baliys and Smith description, which becomes a male dominated representation of a state asserts:

"When we think of characteristics such as power, autonomy, rationality and public, we associate them with masculinity or what it means to be a real man. While, opposite characteristics such as weakness, dependence/connection, emotionality are associated with femininity". (2008: 265)

J Ann Ticker (quoted in Bechler, 2008:1-2), further explain that in hegemonic masculinity, the male and female identities became closely associated with their gender roles frequently suggesting male-identified roles important and deserving compared to female-identified roles. She suggests that men performing the role of 'breadwinners' is an indication of hunting and aggressive while female role of 'housewives' is an indication of gathering and passive. Although, not always easy to pinpoint but this constructed gender identity means, according to feminist scholarship, a distinction between public and private activities and the range of social and familial roles that both men and women possess. Her assessment further suggests that construction of internal boundaries between the 'public' and 'private' realms of society that excluded women from citizenship rights, strongly emphasises men and their masculine role in terms of autonomy, superiority, fraternity, strength, public protector roles and ultimately the bearing of arms' (Bechler, 2008: 2). Meanwhile, 'women were taught to defer, as wives and daughters, to the protection and stronger will of men, while providing the private emotional, economic and social support systems for men's war activities' (ibid.) Tickner later suggests that 'hegemonic masculinity' and its opposite, 'subordinated femininities' show how partial the realist theory is, and highlighted the extent to which mainstream IR thinking relied on gender dichotomies, stereotypes and practises. For these reasons, the feminists argued 
that men have been seen as rightfully operating in the public domain while women have been relegated to the private, because they are seen as weak, peaceful, cooperative and reliant on others for protection. Also, hegemonic masculinity outlined above is "projected [by realists] onto the behaviour of states whose success as international actors is measured in terms of their power capabilities and capacity for self-help and autonomy" (Romaniuk, 2009:145).

She further argues that the realist view point of the state seeking security in the international relations system is based on the "the behaviour of men in positions of public power" (Tickner in Romaniuk, 2009:146). The state is viewed as aggressive, as males are viewed as aggressive. Indeed, for realists, this masculine trait is necessary in an anarchic international system where states are struggling for power. If a state is not aggressive and if it was unable to rely on its own capabilities, it could be seen as weak and dominated by other states. Thus, for realists, while aggressiveness is frowned upon in the private sphere where the state maintains order and which it protects, this trait is encouraged in the public sphere (ibid: 147). Tickner's argument is based her pioneering critique based on the text of Has Morgenthau, a realist theorist and author of 'Politics among Nations' (1948). According to her, Morgenthau's world of politics has a close association between hegemonic masculinity and war. This association is due to the distinction of a masculine and feminine world where masculine characteristics are highly valuable compared to that of feminine. In Morgenthau's world of politics there has been a distinction of masculine and feminine values and where characteristics associated with men have been considered highly valuable compared to women's. Morgenthau defined masculine characteristics and values in terms of 'toughness, courage, power, independence and even physical strength' (Tickner, 1988: 6). On this basis, the 'political man' as defined by Morgenthau is like a nation-state behaves in a form of 'military manhood' (Tickner, 2001:57). In other words, the equation of males/masculinity with aggressiveness precludes any role for females in decision-making processes pertaining to national security. It also proscribes certain activities for women such as war-fighting that are viewed as masculine. Soldiering is the preserve of males who must protect their female compatriots. The state must be prepared for war to guarantee the security of its own.

Tickner later asserts her explanation through another realist theorist, Niccolò Machiavelli. His work further builds upon Morgenthau political man elaborating on the definition of true manliness. His text is focused on the difference between masculine and feminine norm by defining Greek terms such as 'virtue' and 'fortuna'. Machiavelli explained that virtue, which means in literal sense-manly activity, energetic activity and courage, while true women are 'fortuna', originally a Roman goddess associated with capriciousness and unpredictability. Fortuna is presented as feminine power in men themselves against which they must constantly struggle to maintain their autonomy. "The capricious fortuna cannot be prevented but it can be prepared against and overcome through the cultivation 
of manly virtures" (Tickner, 1988:38). In Machiavelli's own words, "Fortuna is a woman, and it is necessary if you wish to master her, to conquer her by force" (Tickner, 1988:39). Tickner indicated that for Machiavelli masculinity is associated with violence and use of force celebrating the male power, particularly the glorification of male the warrior, femininity in contrast to that is an identity, 'inferior' and 'weak'. Though not explicitly implied, Tickner believes that both the realists' texts considered femininity as a threat to masculine values. She further suggested that the traditional realist theory advocates the understanding of masculine power through war and aggression as a dominant practice of international relations even to this day. "Survival in a violence prone international system 'requires' war-capable states peopled by heroic masculine... warriors." (Tickner in Romaniuk, 2009: 147). Another crucial point that Tickner's assessment from her interpretations of realist text has suggested is that image of the heroic masculine warrior is the self-sacrificing and legitimised protector of the citizens particularly of women and children. The notion that young males fight wars to protect vulnerable groups, such as women and children, who cannot be expected to protect themselves, has been the important motivating concept behind military recruitment.

In short, Tickner stresses upon the classical text of Morgenthau and Machiavelli build her critique on how realism as a theory has traditionally been gendered. Morgenthau's political man as well as Machiavelli's 'Virtue' and 'Fortuna' have been the illustrations of hegemonic masculinity representing femininity as a threat and danger against which the masculine state safeguard its interests. As already discussed above that national security at International Relations field is one such field where most of the important decisions are made yet it is where women as head of states, diplomats, and military officials are hardly seen. Again going back to earlier arguments that suggest hegemonic masculinity and patriarchal norms as dominant forces behind states where men conduct politics from their own defined values, experiences and identify, scholars like Tickner have further asserts that masculinities and politics has a long and close association. Characteristics associated with men are 'toughness, courage, power, independence and even physical strength, have throughout the history been valued in the conduct of politics' (Tickner, 1988: 6). Also, frequently, manliness is associated with violence and use of force celebrating the male power, particularly the glorification of male the warrior. Through the text of Has Morgenthau, a realist theorist and author of 'Politics among Nations', Tickner provides an understanding of masculine power through war and aggression as a dominant practice of international relations even to this day. She suggests that classical theorists such as Morgenthau, individuals struggle for power whenever they contact with one another. The family, the political life is all modified only by conditions under the struggle takes place. Morgenthau's world of politics is a distinction of a masculine and feminine world where manly characteristics are highly valuable compared to women's. His 'political man' is like a political state (realist state) that behaves morally in international politics that is bound to failure. Similarly, other theorists like followed 
Machiavelli further asserted upon Morgenthau construction of political man and that true manliness is 'virtue', which means in literal sense-manly activity, energetic activity and courage, while true women are 'fortuna', originally a Roman goddess associated with capriciousness and unpredictability (p.38). Fortuna is presented as feminine power in men themselves against which they must constantly struggle to maintain their autonomy. The capricious fortuna cannot be prevented but it can be prepared against and overcome through the cultivation of manly qualities (ibid).

Machiavelli's "Virtue" and fortuna are the "gendered" representation of how security is understood in world politics. His writings points out to women and feminine characterises has 'inferior' and thus a threat to the sovereignty of nation. Production of 'insecurity' thus becomes a 'social construction' and where it also become necessary for the states to continuously produced the definition as well as possible solution to those 'threat' in order to defend the identity of the State. (Weldes, 1997).

\section{Conclusions}

In this paper, I argued that International Relations field is traditionally dominated in masculine values and identity. The academic discipline is overwhelmingly male and conventional practices of international relations are typically associated with men. Security is still regarded as the core topic of international relations and is preoccupied with power, security, international structures, and relations between states. I also argued that states with masculine perspective appreciate masculine characteristics of power and aggression while devaluing feminine characterises as passive and weak. This concept is influenced with realist theory of IR with is based on the principals of hegemonic masculinity socially constructing certain stereotypical representation on women and men. As argued in the paper, 'women' and 'feminine' identity is considered as a weakness, passive and peaceful and hence threat and dangerous and a threat to security of a state. Similarly, as for states operating in the international system, crisis are social constructed, for masculine states, similar notion can be applied that women as danger and crisis is a phenomenon used and produced socially and not otherwise. Also, masculine state considered this difference as threat to their identity. Hence, to safeguard their identity, women must be represented as a crisis against which masculine state exercise their power, authority for protecting their identity. Also domination of masculine perspective on both theory and decision-making levels of security issues in International Relations is so because decisions that take place in this field affect the lives of women yet where the experiences of women are generally ignored. Although women have made strides professionally over the last century, politics remains a man's world. Significant barriers stand in the way of more women assuming positions of political leadership. If serious efforts are not made to break down these barriers, the world will miss out on the benefits that women can bring to security. 
As a way forward, I am suggesting that feminist scholars have questioned the traditional notion of security arguing how it has resulted in gendering international relations field by marginalising women from the theoretical agenda and by promoting masculine identity as legitimate authority to conduct security. The scholarship has taken the security of people and not states, as their point of departure as well as a broader formulation of security that fosters a non-military dimension. Contemporary Feminist IR understanding of security highlights the importance of recognising and altering the gender inequalities within social relations as a prerequisite for envisioning a more secure world where security is based on the priority of justices. Not only are the experiences of women relevant, but all social relations of subordination must be eliminated.

Finally, states are means to an end, not an end in themselves. Security studies clearly need to evolve to address a changing world. This means acknowledging the importance of non-military security issues and acknowledging the different security experiences of women, so that questions of violence, rape and refugee status are treated with similar seriousness as military strategies. Not only would this allow the experiences of women to be incorporated into security thinking but also open the way for effective consideration of other cultures' unique security needs.

\section{End Notes}

1. The concept of hegemonic masculinity is although based on the definition on work of Robert Connell (1995), in this paper, hegemonic masculinity is explored through contemporary feminist IR perspectives of J Ann Tickner. Contextualising the concept of hegemony in Marxist analysis, Gramsci's theory explains that dominance is maintained through the formation of social groups and ideological ascendency, defining morality, what is natural and normal (Hearn 2004:54; Kronsell 2005:281-82, 84; Peterson and True 1998:17; Hooper 1998:34). Extending this theory, this can be related to hegemonic masculinity as maintenance of the separation of public/private, male/not male as social groups, dependent on the exclusion of feminine agents and values to maintain masculine dominance.

2. There is another category that associates hegemonic masculinity with patriarchy. Very crucial but is not discussed in this paper. There substantial categories of men whose values or behaviour are at odd behaviour with patriarchal order. Example: physically weak men (including gay) and there substantial categories of men whose values or behaviour are at are marginalised in this category because they are not bound by conventional definition of both patriarchy and hegemonic masculinity. Fit in rather loose sense because they adversities an alternative to heterosexual norms. 


\section{References}

Balylis, John, Steve Smith and Patricia Owens., eds. The Globalization of World Politics: An Introduction to International Relations. 2008. Oxford. Oxford University Press.

Bashevkin, Sylvia B. 1985. Toeing the Lines: Women and Party Politics in English Canada. Toronto. University of Toronto Press.

Bechler, Rosemary. 2008. The wrong turn (2): 'hegemonic masculinity'. http://www.opendemocracy.net/article/hegemonic-masculinity (October 23)

Bracher, Michael and Frank P. Harvey eds., 2005. Millennial Reflections on International Studies. United States of America. The University of Michigan Press.

Blanchard, E. M. 2003. "International Relations and the Development of Feminist Security Theory". Chicago Journals. 28:1289-1312.

Burns, N, Schlozman, KL, Verba, S. 1997. "The public consequences of private inequality: Family life and citizen participation”. American Political Science Review. 91:373-389.

Connell, RW and James W. Messerschmitt. 2005. "Hegemonic Masculinity: Rethinking the Concept". Gender And Society. 19:829-859

Cronje, Jean-Marie. 2010. Achieving Visibility in War: An Analysis of Women's Participation in Conflict and Post-Conflict Situations since the End of the Cold War. MA Thesis. University of the Witwatersrand. Available: http://www.genderlinks.org.za/attachment.php?aa id=12092\%E2\%80\%8E

Dudink, Stefan, Karen Hagemann, and John Tosh., eds. Masculinities in Politics and War: Gendering Modern History. 2004. Manchester. Manchester University Press.

Dubois, Ellen Carol. 1975. "The Radicalism of the Woman Suffrage Movement: Notes toward the Reconstruction of Nineteenth Century Feminism". Feminist Studies. 3:36-71.

Elder, Laurel. 2004. "Why Women Don't Run: Explaining Women's Underrepresentation in America's Political Institutions". Women \& Politics. 26: $27-56$. 
Enloe, Cynthia. 2005. "Masculinity As Foreign Policy Issue”. Foreign Policy in Focus. Foreign Policy Briefs 5:36

Hooper, Charlotte. 2001. Manly States: Masculinities, International Relations, and Gender Politics. New York. Columbia University Press.

Hudson, Heidi. 2005. "Doing' Security As Though Humans Matter: A Feminist Perspective on Gender and the Politics of Human Security." Security Dialogue. 36:155-174.

Hunt, Swanee. 2007. “Let Women Rule”. Foreign Affairs. May/June, 109-120

Murphy, Craig N. 1996. "Seeing Women, Recognizing Gender, Recasting International Relations.” International Organization. 50:513-38.

Romaniuk, Scott Nicholas. 2009. "Engaging Gender (In) Security". http://www.genderlinks.org.za/article/engaging-gender-in-security-2010-01-05 (December 7)

Sheehan, Michael. 2005. International Security: An Analytical Survey. Boulder. Lynne Rienner Publishers Inc.

Steans, Jill. 1998. Gender and International Relations. UK. Polity Press.

Schlozman KL, Burns N, Verba S. 1994. Gender and the pathways to participation: the role of resources. The Journal of Politics. 56:963-990

Tickner, J. Ann. 2001. Gendering World Politics: Issues and Approaches in Post-Cold War Era. New York. Columbia University Press.

Tickner, J. Ann. 1992. Gender in the International Relations: Feminist Perspectives on Achieving Global Security. New York. Oxford University Press.

Tickner, J. Ann. 1988. "Hans Morgenthau's Principles of Political Realism: A Feminist Reformulation”. Millennium: Journal of International Studies. 17:429-440.

Trimble, Linda and Jane Arscott. 2004. Still Counting: Women in Politics across Canada. Toronto. University of Toronto Press.

Verba S, Burns N, Schlozman KL. 1997. "Knowing and caring about politics: gender and political engagement". The Journal of Politics. 59:1051-1072. 
Weldes, Jutta, Laffey, Mark, Gusterson, Huge and Duvall, Raymond. eds., 1997. Cultures of Insecurity: States, Communities and the production of Danger. Manneapolis. University of Minnesota Press.

Whitehead, S. M., \& Barrett, F. J. (2001). The sociology of masculinity. In Whitehead, S. M., \& Barrett, F. J. eds. The masculinities reader. Cambridge, UK: Polity.

Saima Siddiqui is Researcher in the Department of Political Science, Memorial University of Newfoundland, Canada. 